\title{
PELAKSANAAN PEMBELAJARAN DARING DI WILAYAH GUGUSAN PULAU KECIL SEGARA ANAKAN
}

\author{
Bekti Dwi Haryoko ${ }^{1 *}$ \\ Agung Nugroho ${ }^{2}$ \\ 1,2Universitas Muhammadiyah Purwokerto, Purwokerto, Indonesia \\ bekti0711@gmail.com ${ }^{1 *}$
}

\begin{abstract}
Abstrak
Penelitian ini bertujuan untuk mengetahui pelaksanaan pembelajaran daring di wilayah gugusan pulau kecil Segara Anakan khususnya di SD N Ujungalang 02, kendala-kendala yang dihadapi oleh guru dan orang tua, serta strategi yang dilakukan oleh guru dan orang tua dalam mengatasi kendala-kendala yang terjadi. Penelitian ini menggunakan metode penelitian kualitatif. Partisipan dalam penelitian ini yaitu kepala sekolah, 3 guru kelas IV sampai VI, 9 peserta didik, dan 9 orang tua. Pengumpulan data dilakukan dengan teknik wawancara, observasi, dan dokumentasi. Hasil penelitian menunjukkan bahwa pelaksanaan pembelajaran daring di SD N Ujungalang 02 dilakukan dengan menggunakan platform Whatsapp group. Whatsapp group dipilih karena dalam penggunaannya tidak memerlukan sinyal yang kuat. Kendala-kendala yang dihadapi guru diantaranya yaitu kualitas jaringan internet yang rendah, penyampaian materi dan beban kuota internet yang bertambah. Orang tua mengalami kendala seperti handphone, kualitas jaringan internet yang rendah, kemampuan terhadap teknologi, beban kuota internet, dan kurang pengawasan kepada anaknya. Adapun strategi yang dilakukan oleh guru dalam mengatasi kendala yang dihadapi yaitu dengan kegiatan guru keliling (guling) dan kegiatan belajar tatap muka terbatas di sekolah. Orang tua menyikapi kendala yang ditemui dengan cara mencari titik sinyal di lokasi tertentu dan berusaha agar kuota internet selalu tersedia supaya anaknya bisa belajar.
\end{abstract}

Kata Kunci: Pembelajaran daring, Kendala guru dan orang tua, Strategi.

Published by:

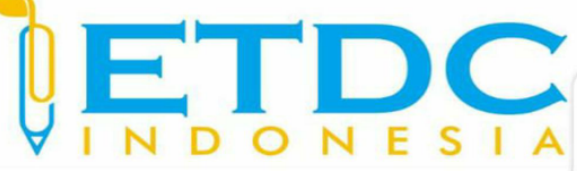

Copyright (C) 2021 The Author (s)

This article is licensed under CC BY 4.0 License

(cc) $\mathrm{BY}$ 


\section{PELAKSANAAN PEMBELAJARAN DARING DI WILAYAH GUGUSAN PULAU KECIL SEGARAANAKAN}

\section{Pendahuluan}

Pendidikan adalah salah satu unsur penting yang dijadikan sebagai tolak ukur kemajuan suatu bangsa. Bangsa bisa dinyatakan maju dapat dilihat atau diukur dari segi kualitas serta sistem pendidikannya. Melalui pendidikan siswa menjadi memiliki bekal pengetahuan dan keterampilan serta mengarah kepada perkembangan dan karakter manusia yang menyeluruh. Pendidikan sekolah dasar bertujuan untuk memberikan pengetahuan, kemampuan atau keterampilan serta kepribadian baik dalam diri peserta didik. Pendidikan di Indonesia saat ini mengalami perubahan dalam pelaksanaannya, pendidikan yang awalnya dilaksanakan secara tatap muka di kelas untuk saat ini dialihkan dengan pembelajaran daring. Hal tersebut dikarenakan adanya pandemi Covid-19.

Salah satu upaya untuk mengantisipasi penyebaran Covid-19, Pemerintah mengeluarkan surat edaran tentang pelaksanaan pendidikan di masa darurat Covid-19 yaitu dengan melaksanakan pembelajaran di rumah melalui daring atau jarak jauh tanpa bertatap muka langsung dengan peserta didik (Kemendikbud. 2020). Pembelajaran adalah kegiatan belajar mengajar yang dilaksanakan oleh siswa dan guru yang menciptakan kegiatan timbal balik. Pembelajaran menurut (Oemar 2011) adalah suatu kegiatan yang terdiri dari unsur manusiawi, material, fasilitas, perlengkapan dan prosedur yang membentuk kombinasi untuk mencapai tujuan. Pembelajaran daring adalah kegiatan belajar yang dilakukan dengan memanfaatkan kemajuan teknologi serta alat komunikasi dalam pelaksanaannya. Pembelajaran daring menurut (Komarudin and Prabowo 2020) adalah pembelajaran yang dilaksanakan dengan tidak bertatap muka dan memberikan kebebasan kepada peserta didik untuk belajar dimana saja serta tidak terikat oleh waktu. Pembelajaran daring menurut (Sadikin et al. 2020) adalah semua kegiatan pembelajaran yang dilakukan secara jarak jauh dengan menggunakan jaringan internet dan didukung oleh berbagai alat komunikasi serta media kelas virtual. Penggunaan teknologi mobile menurut (Korucu and Alkan 2011) memiliki sumbangan besar di bidang pendidikan, salah satunya yaitu dalam pencapaian tujuan pembelajaran jarak jauh. Pelaksanaan pembelajaran secara daring dilaksanakan dengan menggunakan teknologi yang menuntut guru dan siswa harus menguasainya.

Menurut penelitian dari (Rigianti 2020) yang menyatakan bahwa perubahan pembelajaran dari tatap muka menjadi daring memberikan bermacam-macam reaksi dan 
kendala terhadap pelaksanaan pendidikan di Indonesia. Dengan adanya kendala-kendala yang muncul dalam dunia pendidikan pada saat ini, peneliti merasa tergugah untuk menyelidiki pelaksanaan pembelajaran di Wilayah Gugusan Pulau Kecil Segara Anakan. Segara Anakan merupakan laguna air payau yang memisahkan Pulau Nusakambangan di sebelah Selatan dan Pulau Jawa di sebelah Utara. Kecamatan Kampung Laut merupakan gugusan pulau-pulau kecil yang terdapat di wilayah Segara Anakan yang kemudian terbentuk pemukiman atau desa. Desa yang terdapat di Kecamatan Kampung Laut yaitu Desa Ujungalang, Desa Klaces, Desa Ujunggagak, dan Desa Panikel. Wilayah Segara Anakan memiliki karaktersitik wilayah perairan, letaknya cukup jauh dengan pusat kota dan memiliki keterbatasan atau perbedaan fasilitas-fasilitas dibandingkan dengan wilayah yang berada di pusat kota tak terkecuali dalam bidang pendidikan. Letaknya cukup terpencil dan dapat ditempuh melalui dua jalur, yaitu jalur darat dan jalur laut. Letak geografis Kampung Laut terletak di sisi barat Jawa Tengah dan berbatasan dengan Jawa Barat.

Penelitian yang dilakukan oleh (Mastura and Santaria 2020) menyebutkan beberapa kendala yang ditemui pada pelaksanaan pembelajaran daring yaitu fasilitas yang kurang memadai yang membuat motivasi belajar peserta didik berkurang, tidak semua guru mahir dalam menggunakan teknologi terutama di lingkungan pedesaan, penambahan biaya kuota internet yang dirasakan oleh guru dan orang tua, dan metode, gaya, dan strategi guru dalam pembelajaran harus berubah dan disesuaikan dengan pembelajaran secara online. Selanjutnya penelitian dari (Anugrahana 2020) yang menyebutkan kendala dalam pembelajaran daring diantaranya yaitu siswa yang merasa bosan, orang tua tidak bisa menjelaskan secara detail kepada siswa, sinyal yang lemah, dan pendampingan orang tua kurang karena pekerjaan. Kegiatan pembelajaran tatap muka yang dialihkan menjadi daring saat ini memberikan pengalaman kepada berbagai pihak, tak terkecuali bagi guru, peserta didik, dan orang tua yang berada di wilayah pedesaan. Berdasarkan uraian tersebut, peneliti ingin melakukan penelitian di Wilayah Gugusan Pulau Kecil Segara Anakan yang terletak di wilayah yang cukup jauh dari perkotaan dan memiliki perbedaan terkait dengan fasilitas-fasilitas penunjang dalam proses pembelajaran yang dimiliki dibandingkan dengan wilayah perkotaan. Penelitian ini bertujuan untuk mengetahui pelaksanaan pembelajaran daring yang dilakukan dan kendala-kendala yang dihadapi oleh guru dan orang tua serta strategi yang dilakukan oleh guru dan orang tua dalam mengatasi kendala-kendala yang dihadapi.

\section{Metode Penelitian}

Penelitian ini merupakan jenis penelitian kualitatif dengan subjek penelitian berjumlah 
22 partisipan yang terdiri dari kepala sekolah, 3 guru kelas tinggi, 9 siswa kelas tinggi, dan 9 orang tua. Penelitian ini dilakukan di SD N Ujungalang 02 yang terletak di Kecamatan Kampung Laut. Peneliti berperan sebagai instrumen kunci penelitian dengan melaksanakan penelitian menggunakan instrumen berupa pedoman wawancara dan pedoman observasi. Peneliti berperan sebagai pewawancara langsung untuk menggali data kepada partisipan penelitian. Data-data penelitian yang diperoleh selanjutnya dianalisis. Teknik analisis data terdiri dari tahap pengumpulan data, reduksi data, penyajian data, dan menyimpulkan data.

\section{Hasil dan Pembahasan}

\section{Pelaksanaan pembelajaran daring yang dilakukan}

Pelaksanaan pembelajaran di SD N Ujungalang 02 dilaksanakan secara daring. Berdasarkan hasil wawancara dengan pihak sekolah dan peserta didik serta orang tua dapat diketahui bahwa pelaksanaan pembelajaran daring di SD N Ujungalang 02 dilaksanakan dengan menggunakan platform Whatsapp group. Penentuan platform yang digunakan dengan mempertimbangkan kondisi letak geografis wilayah tersebut. Letak geografis wilayah yang didominasi wilayah perairan serta jauh dari pusat kota memunculkan berbagai kesenjangan salah satunya yaitu rendahnya kualitas jaringan internet. Platform whatsapp group dipilih karena dalam penggunaannya tidak memerlukan sinyal yang kuat. Hal tersebut sesuai dengan pernyataan Bilfaqih \& Qomarudin, 2015 (Jayul and Irwanto 2020) pembelajaran daring merupakan pembelajaran yang dilaksanakan dengan memanfaatkan teknologi dan berbagai media seperti video, kelas virtual dan yang lainnya. Penggunaan platform whatsapp group yang digunakan sebagai sarana kegiatan belajar mengajar oleh guru sejalan dengan yang diungkapkan oleh (Bhagaskara, Nur Afifah, and Maulana Putra 2021) bahwa aplikasi whatsaap dapat diterapkan dalam proses pembelajaran daring dan mampu mengakomodasi pembelajaran daring dengan baik. Pemanfaatan aplikasi whatsapp dalam pembelajaran daring dapat memberikan pengalaman bagi peserta didik. Kegiatan pembelajaran daring yang dilaksanakan terdiri dari tiga tahap yaitu kegiatan awal, kegiatan inti, dan kegiatan penutup. Hal tersebut sesuai dengan hasil temuan penelitian (Prasetyo and Zulela 2021) yang menyatakan proses pelaksanaan pembelajaran daring dengan whatsapp melalui tiga tahapan yaitu berkomunikasi, penyampaian, dan pengumpulan tugas belajar siswa. Guru memberikan materi yang akan dipelajari yang terdapat pada buku pendamping peserta didik serta membagikan link Youtube untuk disimak maupun dipelajari oleh siswa. Hal tersebut sejalan dengan yang dinyatakan oleh (Prasetyo and Zulela 2021) yaitu guru memadukan inovasi 
pembelajaran daring menggunakan aplikasi whatsapp dengan video youtube. Kegiatan pembelajaran daring yang dilaksanakan membuat guru harus mampu meningkatkan kembali semangat belajar peserta didik dengan berbagai cara. Hal tersebut sesuai dengan hasil penelitian dari (Pandemic, Yu, and Jee 2021) mengungkapkan bahwa pemberian umpan balik yang tepat kepada peserta didik dapat memotivasi peserta didik secara terus-menerus.

\section{Kendala yang dihadapi oleh guru dan orang tua}

1. Guru

a) Kualitas jaringan internet yang rendah

Jaringan internet merupakan komponen penting dalam melaksanakan kegiatan pembelajaran secara daring. Kuat atau tidaknya jaringan internet berpengaruh terhadap kegiatan pembelajaran yang dilaksanakan. Berdasarkan hasil penelitian didapatkan bahwa kualitas sinyal atau jaringan internet di wilayah SD N Ujungalang 02 rendah atau kurang memadai sehingga menjadi kendala bagi guru. Kendala yang dihadapi oleh guru salah satunya yaitu kualitas jaringan yang rendah. Kuat atau tidaknya jaringan internet berpengaruh terhadap kegiatan pembelajaran yang dilaksanakan. Sejalan dengan yang disampaikan oleh (Rigianti 2020) yang menyebutkan bahwa minimnya akses internet dan gawai merupakan kendala yang ditemui pada pelaksanaan pembelajaran daring. Senada dengan hal tersebut (Anugrahana 2020) juga menyatakan bahwa sinyal merupakan salah satu penghambat dalam melaksanakan pembelajaran daring. Sinyal atau jaringan internet merupakan faktor pendukung dalam pelaksanaan pembelajaran daring.

b) Penyampaian materi

Guru melaksanakan pembelajaran daring dengan memberikan materi kepada peserta didik. Berdasarkan hasil wawancara dengan guru diperoleh informasi bahwa penyampaian materi juga menjadi kendala dalam melaksanakan pembelajaran secara daring. Penyampaian materi yang dilakukan di Whatsapp group memberikan pengalaman yang berbeda bagi guru. Penyampaian materi yang dilakukan menjadi kendala bagi guru dalam mengetahui pencapaian pemahaman siswa terhadap materi yang disampaikan. Penyampaian materi merupakan hal penting yang harus dilakukan oleh guru dalam melaksanakan kegiatan belajar mengajar tak terkecuali secara daring. Penyampaian materi secara daring melalui Whatsapp group menjadi hal yang baru bagi guru sehingga guru mengalami kesulitan. Sejalan dengan yang dinyatakan oleh (Mastura and Santaria 2020) menyebutkan kendala yang ditemui pada pelaksanaan pembelajaran daring yaitu metode, gaya, dan strategi guru dalam pembelajaran harus berubah dan disesuaikan dengan pembelajaran secara online. Guru kesulitan dalam 
mengetahui pencapaian pemahaman siswa terhadap materi yang disampaikan.

c) Beban kuota internet

Pembelajaran daring yang dilakukan oleh guru juga membutuhkan kuota internet. Berdasarkan hasil wawancara dengan pihak sekolah menyatakan bahwa dengan adanya pembelajaran daring ini membuat pengeluaran yang semakin bertambah. Hal tersebut dikarenakan kebutuhan kuota internet yang bertambah.

Kuota internet dibutuhkan oleh guru untuk menjalankan atau melaksanakan kegiatan belajar mengajar secara daring. Hal tersebut mengakibatkan pengeluaran guru yang semakin bertambah untuk memenuhi kuota internet agar dapat melaksanakan kegiatan belajar dengan peserta didik. Sejalan yang diungkapkan oleh (Mastura and Santaria 2020) menyebutkan bahwa penambahan biaya kuota internet yang dirasakan oleh guru dan orang tua. Pembelajaran daring yang dilaksanakan mengakibatkan pengeluaran atau biaya orang tua menjadi meningkat.

2. Orang tua

a) Handphone

Salah satu alat komunikasi yang bisa dijadikan sebagai alat untuk melaksanakan kegiatan pembelajaran daring salah satunya yaitu handphone. Bagi orang fasilitas handphone manjadi salah satu kendala dalam melaksanakan pembelajaran daring. Dari hasil penelitian diketahui bahwa peserta didik belum diberikan fasilitas handphone sendiri oleh orang tua. Sebanyak 5 orang tua mengatakan bahwa peserta didik dalam melaksanakan kegiatan belajar secara daring menggunakan handphone orang tua atau kakaknya, dan 1 orang tua tidak memiliki, serta 3 orang tua menyatakan bahwa anaknya sudah memakai handphone sendiri. Handphone merupakan alat komunikasi yang bisa digunakan untuk melaksanakan kegiatan belajar. Handphone yang sejatinya menjadi salah satu faktor penentu keberhasilan proses pembelajaran justru menjadi kendala bagi orang tua. Sebagaimana yang diungkapkan oleh (Anugrahana 2020) yang menyatakan ada siswa yang belum memiliki handphone dan ada yang sudah memiliki tetapi terkendala dengan sinyal. Peserta didik dalam melaksanakan kegiatan belajar secara daring menggunakan alat komunikasi atau handphone orang tua atau kakaknya.

b) Kualitas Jaringan Internet

Kualitas jaringan internet juga menjadi kendala bagi orang tua dalam memberikan pendampingan kepada anaknya dalam pelaksanaan pembelajaran daring. Hasil penelitian menunjukkan bahwa hampir dari 9 responden orang tua menyatakan bahwa jaringan internet 
atau sinyal yang terdapat di rumahnya kurang memadai. Peserta didik ketika melaksanakan kegiatan belajar harus mencari sinyal di titik tertentu. Jaringan internet merupakan komponen penting dalam melaksanakan kegiatan pembelajaran secara daring. Kuat atau tidaknya jaringan internet berpengaruh terhadap kegiatan pembelajaran yang dilaksanakan. Jaringan internet yang terdapat di tempat atau rumah orang tua peserta didik kurang memadai. Hal tersebut sejalan dengan hasil penelitian dari (Rigianti 2020) yang menyatakan bahwa minimnya akses internet menjadi kendala dalam pelaksanaan pembelajaran daring. Kualitas jaringan internet yang rendah menghambat lancarnya kegiatan belajar mengajar yang dilaksanakan baik bagi guru, siswa, dan orang tua.

c) Kemampuan terhadap teknologi

Kemampuan terhadap teknologi perlu dimiliki oleh guru, peserta didik, dan orang tua. Hasil penelitian ditemukan bahwa kemampuan terhadap teknologi ini menjadi salah satu kendala bagi orang tua. Dari hasil penelitian ditemukan bahwa terdapat 6 dari 9 orang tua menyatakan belum mampu menggunakan Handphone dengan baik dan sisanya sudah bisa menggunakannya. Kemampuan teknologi dibutuhkan untuk memperlancar dalam melaksanakan pembelajaran daring sehingga orang tua dapat mendampingi anak dalam belajar dengan maksimal. Kemampuan terhadap teknologi ini perlu dimiliki oleh guru, peserta didik, dan orang tua. Hasil penelitian ditemukan bahwa terdapat orang tua yang belum memiliki kemampuan teknologi dengan baik sehingga menjadi kendala. Sebagaimana yang diungkapkan oleh (Mastura and Santaria 2020) menyatakan bahwa kendala yang ditemui pada pelaksanaan pembelajaran daring yaitu tidak semua guru dan orang tua mahir dalam menggunakan teknologi terutama di lingkungan pedesaan. Orang tua peserta didik masih belum mampu dalam menggunakan alat komunikasi dengan baik.

d) Beban Kuota Internet

Pembelajaran daring yang dilaksanakan juga memerlukan adanya kuota internet. Kuota internet yang dikeluhkan oleh guru juga menjadi kendala bagi orang tua. Berdasarkan hasil penelitian ditemukan bahwa kuota internet yang dibutuhkan dalam melaksanakan pembelajaran daring bagi orang tua menjadi beban tersendiri. Pembelajaran daring yang dilaksanakan mengakibatkan pengeluaran atau biaya orang tua menjadi meningkat. Kuota internet juga dibutuhkan dalam kegiatan pembelajaran daring untuk menggunakan platform yang digunakan dalam kegiatan belajar mengajar. Kuota internet yang dibutuhkan dalam pelaksanaan pembelajaran daring ini menjadi beban bagi orang tua yang mengakibatkan pengeluaran semakin meningkat. Sesuai dengan yang diungkapkan oleh (Mastura and 
Santaria 2020) menyebutkan bahwa penambahan biaya kuota internet yang dirasakan oleh guru dan orang tua. Pembelajaran daring yang dilaksanakan mengakibatkan pengeluaran atau biaya orang tua menjadi meningkat.

e) Kurangnya Pengawasan

Pembelajaran daring dalam pelaksanaannya tidak hanya dilakukan oleh guru dan peserta didik saja, akan tetapi orang tua juga memiliki peran didalamnya. Orang tua memiliki peran memberikan pendampingan kepada peserta didik dalam melaksanakan kegiatan belajar. Hasil penelitian didapatkan bahwa orang tua kurang dalam memberikan pengawasan kepada anaknya. Orang tua kurang dalam memberikan pendampingan belajar kepada anaknya dikarenakan orang tua yang harus bekerja atau memiliki kesibukan tersendiri. Orang tua memiliki peran memberikan pendampingan kepada peserta didik dalam melaksanakan kegiatan belajar. Orang tua yang semestinya memberikan pendampingan secara berkelanjutan kepada peserta didik, akan tetapi yang terjadi di lapangan bertolak belakang. Hal tersebut sejalan dengan (Rigianti 2020) yang menyebutkan kurangnya pengawasan orang tua kepada anak dalam pembelajaran daring. Orang tua kurang dalam memberikan pendampingan belajar kepada peserta didik karena memiliki kesibukan atau harus bekerja.

\section{Strategi guru dan orang tua dalam mengatasi kendala-kendala yang dihadapi}

1. Guru

a) Guru keliling (guling)

Guru keliling (guling) menjadi salah satu strategi yang dilakukan oleh pihak guru. Berdasarkan hasil wawancara dengan pihak sekolah yang menyatakan bahwa guling menjadi salah satu strategi yang dilakukan untuk mengatasi kendala-kendala yang terjadi saat pembelajaran daring. Kegiatan guru keliling bertujuan untuk mengajarkan materi kepada siswa secara berkelompok. Kegiatan guling pada intinya sama dengan kegiatan home visit. Pelaksanaannya yaitu guru mengajarkan materi kepada peserta didik dengan sistem berkelompok. Kegiatan belajar yang dilakukan biasanya dilaksanakan di rumah siswa dengan mematuhi protokol kesehatan seperti memakai masker. Guru mengajarkan materi dari kelompok satu ke kelompok yang lain secara bergantian dengan mengajarkan materi yang sama. Guru beranggapan bahwa strategi tersebut merupakan salah satu strategi yang dapat dilakukan agar siswa dapat menerima pembelajaran dengan baik. Sejalan dengan hasil penelitian (Nirmala and Annuar 2021) yang mengungkapkan bahwa strategi home visit merupakan salah satu solusi yang dapat dilakukan untuk tetap memberikan layanan pembelajaran kepada peserta didik. Selanjutnya penelitian yang dilakukan oleh (Mokodompit 
2020) menyatakan bahwa home visit membantu guru mendapatkan informasi mengenai kendala yang dihadapi oleh siswa dan orang tua selama pembelajaran jarak jauh dilaksanakan serta memberikan pelayanan dengan mengajarkan materi kepada siswa yang tidak bisa mengikuti pembelajaran online. Terlepas dari efektifnya kegiatan guling ini, akan tetapi dalam pelaksanaannya membutuhkan tenaga yang ekstra bagi guru karena guru harus memberikan materi yang sama kepada beberapa kelompok secara bergantian.

b) Belajar tatap muka secara terbatas

Kegiatan belajar tatap muka terbatas di sekolah juga dilakukan sebagai strategi untuk mengantisipasi kendala yang muncul saat pembelajaran daring. Dari hasil penelitian ditemukan bahwa kegiatan belajar tatap muka secara terbatas dilaksanakan dengan mematuhi protokol kesehatan serta waktu pelaksanaannya sesuai dengan masing-masing guru kelas. Kegiatan tersebut dianggap menjadi salah satu strategi yang efektif untuk dilakukan di lokasi tersebut. Kegiatan belajar tatap muka secara terbatas di sekolah dilaksanakan dengan mematuhi protokol kesehatan seperti memakai masker dan dilaksanakan dengan membentuk 2 kelompok secara bergantian, serta tidak dengan menggunakan seragam sekolah. Strategi tersebut dianggap efektif untuk dilaksanakan, melihat kondisi wilayah yang kurang memadai dari segi jaringan serta keterbatasan fasilitas yang terdapat di wilayah tersebut.

c) Orang tua

Berdasarkan hasil penelitian orang tua hanya menyikapi kendala terkait dengan kualitas jaringan internet yang rendah dan kuota internet yang menjadi beban. Sulitnya jaringan internet diatasi oleh orang tua dengan mencari jaringan di titik tertentu biasanya dilakukan di luar ruangan dengan memposisikan handphone terlebih dahulu atau dengan memanfaatkan jaringan wifi di sekolah atau di balai desa. Selain jaringan internet, kuota internet juga menjadi kendala bagi orang tua yang mengakibatkan meningkatnya pengeluaran. Orang tua dalam mengatasi beban kuota internet dengan cara mengusahakan untuk tetap tersedia kuota internetnya agar bisa digunakan untuk belajar oleh anaknya walaupun tidak jarang orang tua terlambat dalam menyediakan kuota internet karena uang atau biaya yang belum tersedia.

\section{Kesimpulan dan Saran}

Berdasarkan hasil penelitian dapat disimpulkan bahwa pelaksanaan pembelajaran daring yang dilakukan di Wilayah Gugusan Pulau Kecil Segara Anakan khususnya di SD N Ujungalang 02 dilaksanakan dengan menggunakan platform Whatsapp group. Platform 
Whatsapp group dipilih karena dalam penggunaannya tidak memerlukan sinyal yang kuat. Kegiatan pembelajaran daring yang dilaksanakan memunculkan berbagai kendala bagi guru dan orang tua. Guru mengalami kendala seperti kualitas jaringan internet yang rendah, penyampaian materi, dan beban kuota internet. Orang tua juga mengalami kendala seperti fasilitas handphone, kualitas jaringan internet yang rendah, kemampuan terhadap teknologi, beban kuota internet, dan kurang memberikan pengawasan kepada anaknya. Adapun strategi dan temuan dari penelitian ini yaitu guru melakukan kegiatan guru keliling (guling) dan kegiatan belajar tatap muka terbatas di sekolah sebagai upaya untuk mengatasi kendalakendala yang dihadapi dalam pelaksanaan pembelajaran daring. Orang tua menyikapi kendala yang ditemui dengan cara mencari titik sinyal di lokasi tertentu dan berusaha agar kuota internet selalu tersedia supaya anaknya bisa belajar.

Saran yang dapat diberikan yaitu guru diharapkan memberikan materi pembelajaran yang bervariasi dengan disertai video pembelajaran yang terdapat di youtube dan guru diharapkan dapat mencoba platform lain agar siswa memiliki pengalaman yang bertambah dalam pembelajaran daring. Selanjutnya bagi orang tua, orang tua diharapkan meluangkan waktu yang lebih untuk memberikan pendampingan belajar kepada siswa dan memberikan motivasi agar siswa semangat belajar.

\section{DAFTAR PUSTAKA}

Anugrahana, Andri. 2020. "Hambatan, Solusi Dan Harapan: Pembelajaran Daring Selama Masa Pandemi Covid-19 Oleh Guru Sekolah Dasar." Scholaria: Jurnal Pendidikan Dan Kebudayaan 10 (3): 282-89. https://doi.org/10.24246/j.js.2020.v10.i3.p282-289.

Bhagaskara, Arindra Evandian, Eka Nur Afifah, and Enggar Maulana Putra. 2021. "Pembelajaran Dalam Jaringan (DARING) Berbasis WhatsApp Di SD Yapita." ZAHRA: Research and Tought Elementary School of Islam Journal 2 (1): 13-23. https://doi.org/10.37812/zahra.v2i1.183.

Jayul, Achmad, and Edi Irwanto. 2020. "Model Pembelajaran Daring Sebagai Alternatif Proses Kegiatan Belajar Pendidikan Jasmani Di Tengah Pandemi Covid-19 Achmad." Jurnal Pendidikan Kesehatan Rekreasi 6 (2): 190-99.

Kemendikbud. 2020. Surat Edaran Nomor 4 Tahun 2020 Pada Tanggal 24 Maret 2020 Berisi Tentang Pelaksanaan Kebijakan Pendidikan Dalam Masa Darurat Peyebaran COVID19. Jakarta: Kemendikbud.

Komarudin, and Mardianto Prabowo. 2020. "Persepsi Siswa Terhadap Pembelajaran Daring Mata Pelajaran Pendidikan Jasmani Olahraga Dan Kesehatan Pada Masa Pandemi Covid-19.” Majalah Ilmiah Olahraga (MAJORA) 26 (2): 56-66.

Korucu, Agah Tugrul, and Ayse Alkan. 2011. "Differences between M-Learning (Mobile 
Learning) and e-Learning, Basic Terminology and Usage of m-Learning in Education." Procedia - Social and Behavioral Sciences 15: 1925-30. https://doi.org/10.1016/j.sbspro.2011.04.029.

Mastura, and Rustan Santaria. 2020. "Dampak Pandemi Covid-19 Terhadap Proses Pengajaran Bagi Guru Dan Siswa.” Jurnal Studi Guru Dan Pembelajaran 3 (2): 634.

Mokodompit, Intan Safitri. 2020. "Home Visit Sebagai Refleksi Kurikulum Darurat Covid19: Kesiapan Guru , Respon Siswa, Materi Dan Hasil Belajar Di Madrasah Tsanawiyah" 6 (2): 119-31.

Nirmala, Besse, and Haerul Annuar. 2021. "Home Visit: Strategi PAUD Dari Rumah Bagi Guru Di Daerah 3T Pada Masa Pandemi Covid-19” 5 (2): 1052-62. https://doi.org/10.31004/obsesi.v5i2.716.

Oemar, Hamalik. 2011. Proses Belajar Mengajar. Jakarta: Bumi Aksara.

Pandemic, Covid-, Jieun Yu, and Yongseok Jee. 2021. "Education Sciences Analysis of Online Classes in Physical Education during The."

Prasetyo, Teguh, and M.S. Zulela. 2021. "Proses Pembelajaran Daring Guru Menggunakan Aplikasi Whatsapp Selama Proses Pembelajaran Daring Guru Menggunakan Aplikasi Whatsapp." Jurnal Elementaria Edukasia 4 (1): 138-50. https://doi.org/10.31949/jee.v4i1.2769.

Rigianti, Henry Aditia. 2020. "Kendala Pembelajaran Daring Guru Sekolah Dasar Di Banjarnegara" 7 (2): 297-302. http://mpoc.org.my/malaysian-palm-oil-industry/.

Sadikin, Ali, Afreni Hamidah, Kampus Pinang, Masak Jl, Jambi Ma, Bulian Km, Mendalo Indah, Kec Jaluko, Kab Muarojambi-jambi Kode, and Pos Indonesia. 2020. "Pembelajaran Daring Di Tengah Wabah Covid-19 ( Online Learning in the Middle of the Covid-19 Pandemic )" 6 (1): 214-24. 